\title{
Tooting our horn
}

$\mathrm{M}$

y much older cousin, Ladislav, was the trumpet player. He let me play his trumpet, only once, when I was quite young. After my brief squealing session, I decided it was not an instrument I wanted to master. It is only now, many years later, that I have decided it is time to 'toot my horn'.

As human beings, some of us are fortunate enough to be able to direct the course of our lives. I was one of them. I spent most of my working life publishing peer-review medical journals. Looking back at the 33 years devoted to this profession, I can recall the trying times, but mostly remember the good ones. There is a wonderful feeling holding a new issue of a journal, which I have done hundreds of times. And that kind of joy sustained me throughout the many times when I was going to throw the towel in. Although I wouldn't have had the chance to meet as many accomplished and engaging people in any other endeavour, I can tell you from experience, peer-review publishing is not the road to riches.

In 1984, when I started the company, there were only a few Canadian peer-review medical journals, but no Canadian journals of Cardiology, Gastroenterology, Infectious Diseases, Pain, Paediatrics or Respiratory medicine. We launched them all, and at least a dozen others.

We WERE (are) good! Thanks to our editorial staff, now led by Brian Vukusic, I believe there is no medical publishing company in the world that comes close to the quality of scientific English we have been publishing. We were one of the few medical publishing companies providing physicians with free journals as well as supporting Societies from revenues for their endorsement. Additionally, the journals were somewhat reluctantly and intermittently supported by advertising from some pharmaceutical companies.

This model is no longer sustainable. Pharmaceutical companies have largely dropped their support of journals. Authors demand open access for a publishing fee. Only publishers that have many journals can survive.
It all started with the Canadian Journal of Cardiology and Dr Robert Beamish, a humble genius. Thanks to him and Dr Naranjan Dhalla, that journal still exists, and its spin-off, Current Research: Cardiology, was launched thanks to Dr Bohuslav Ostadal. There were so many others that played a part throughout the years. In the beginning, my father-in-law, the late Dr Edwin Blakley, did the editing free of charge. Many other scientists offered free time and advice. Janet O'Flaherty brought her expertise with medical publishing from England with her husband John; Andrea Holter, the Director of Administration of many years, kept the business on level ground; and, most important, my Vice President and friend, Ann LeBlanc, kept me focused and the business humming. It couldn't have happened without them and all the other employees over the years. I also thank all the Editors-in-Chief, especially those who truly devoted all their efforts to the success of their journals and, of course, the reviewers, without whom the peer review system could not exist.

Personally, my wife Diane supported the family at the beginning and throughout the unprofitable years.

The time has come - not to throw in the towel, but to pass the torch. This is (probably) the last issue of any journal I publish. Pulsus has been sold. In 33 years, any kind of business goes through changes and medical publishing is no exception. The keepers of that passed flame have a totally different approach essential to keeping the flame burning.

This issue of the Journal celebrates the 80th birthday of Professor Dhalla. He was also able to determine the course of his very successful life. I wish him to continue in his productive life for years to come.

With this issue, I close the largest chapter in my life and say goodbye to my readers, my employees, and all the great scientists, clinicians and authors. WE will be missed. Toot!

Robert B Kalina, Publisher 